\title{
The Implementation of Micro Small Medium Enterpise (MSME) Accounting in Credits to Financial Institutions
}

\author{
Rakhmini Juwita \\ Accounting Department, Faculty of Economics Universitas Terbuka, Indonesia \\ rakhmini@ecampus.ut.ac.id
}

\begin{abstract}
MSME can encourage economic growth, social stability, and the development of the business world in Indonesia. Hence, the government attempts to increase MSME competitiveness to become a sustainable business on a larger scale. To realize this, MSME requires additional capital through bank loans. The purpose of this study is to determine the implementation of accounting at MSME in three provinces that have the most MSMEs, i.e., West Java, Central Java, and East Java. Moreover, this study also purposes at revealing the effect of accounting implementation on credit to financial institutions. This study involved seventy-five MSME respondents. The results of the study indicated that the implementation of accounting at MSMEs in the Provinces of West Java, Central Java, and East Java had been well implemented. However, the provision of credit by financial institutions was still considered sufficient since lending by financial institutions was not in accordance with the loan application proposed by MSMEs.
\end{abstract}

Keywords

MSME accounting,

credit implementation

\section{Introduction}

Micro, Small, and Medium Enterprises (MSMEs) have a vital role in the growth of economic development such as overcoming the problem of unemployment and poverty. With the growth of MSMEs will increase income and can reduce poverty of Indonesian people. According to data from the Ministry of Cooperatives and SME, the proportion of MSMEs is $99.98 \%$ of the total business units in Indonesia. The contribution of MSMEs to Gross Domestic Product (GDP) reaches sixty-one percent while the contribution of cooperatives to GDP reaches approximately 23.12 percent. However, the large amount and lucrative business potential have not contributed significantly to the economy, such as the contribution to exports in 2013 that amounted to $14.05 \%$ in Indonesia. It was due to several obstacles such as licensing, funding, technology utilization, public purchasing power or consumption, and the level investment both Domestic Investment (PMDN) and Foreign Investment (PMA) that become the two main sectors of economic growth. Conversely, with a business unit portion of only 0.01 percent, the portion of the workforce is only 2.7 percent. The large corporations or companies can contribute 41 percent of the Gross Domestic Product (GDP). It means that MSME productivity is still very low due to issues of efficiency, effectiveness, business ability, and lack of capital. The Government of the Republic of Indonesia was formed to protect the whole of the Indonesian people and all of Indonesia's blood, to promote public welfare, to educate the life of the nation and to carry out world order based on eternal peace and social justice for all Indonesian people. (Angelia, et al. 2020) 
The government is considering the importance of MSMEs in promoting economic growth, social stability, and the development of the business world in Indonesia. Thus, the government is attempting to improve MSME competitiveness to become sustainable businesses on a larger scale. According to the Ministry of Cooperatives and Small and Medium Enterprises (2015), the role of MSMEs will not be optimal if MSMEs face obstacles in accessing formal financial services. Without access to financial service institutions, the creation and growth of business and the opportunity of the community to be economically and socially independent can be hampered. Therefore, the government sets MSME targets in the 2015-2019 RPJMN (National Medium Term Development Plan 2015-2019). The aforementioned target is regarding increasing the proportion of MSMEs to assess formal financing with a target of $25 \%$ of MSMEs having a credit account at the bank. It is done to improve the financing and performance of MSMEs in Indonesia. To make it easier for MSMEs to obtain credit at formal financial institutions, reports should be created so that MSME performance can be recorded in these reports. In general, the performance of MSMEs fails due to lack of planning, marketing knowledge, lacks managerial skills, and has no competency in reporting (Kamyabi and Susela, 2011).

It can be referred that MSMEs realize the need for additional capital through bank loans. However, it has not yet reached the government's target of reaching access financing with a proportion of $25 \%$ of MSMEs having credit accounts at the bank to improve MSME performance. The reason for not achieving the government's target is the lack of adequate information in the form of financial reports produced by the MSMEs.

Based on the background above, it is revealed that the formulations of the problem in this study are as follows:

1. How is the implementation of Accounting at MSMEs?

2. How does accounting effect the provision of credit by financial institutions to MSMEs?

\section{Review of Literature}

\subsection{Micro, Small, and Medium Enterprises}

According to Law No. 20/2008, Micro Enterprise is a productive business owned by individuals and/or individual business entities that meet the Micro-Enterprise criteria based on the Law. Small Enterprise is a productive economic business that stands alone, which is performed by individuals or business entities that are not subsidiaries or branch companies that are owned, controlled, or become a part either directly or indirectly of Medium Enterprises or Large Enterprises that meet the Small Enterprise as referred to the Law. Medium Enterprise is a productive economic business that is self-employed and performed by individuals or business entities that are not subsidiaries or branch companies that are owned, controlled or became a part either directly or indirectly with Small Enterprise or Large Enterprise with the number of net assets or annual sales results as stipulated in the Law.

The criteria of Micro, Small, and Medium Enterprises (MSMEs) based on Law No.20 of 2008 are as follows:
a. Micro-Enterprise Criteria
b. Small Enterprise Criteria
c. Medium Enterprise Criteria 


\subsection{Accounting}

Kieso (2011) defined accounting in the three significant characteristics, i.e., (1) identification, (2) measurement (3) communication of financial information about economic entities to the interested users. Definition of accounting according to the Accounting Principle Board (APB) Statement No. 4 is a service activity whose function is to provide quantitative information, generally in terms of money. It concerns an economic entity that is intended to be used in economic decision making, which is used in selecting several alternatives.

In the financial management of an entity, various interested parties need information. Hence, an accounting report with various processes called the accounting cycle is needed. According to Rudiantoro (2012), the accounting cycle is the sequence of work that must be completed by accountants from the beginning to produce the company's financial statements. The stages in the accounting cycle consist of :

1. Transaction

2. Basic document

3. Journal entry

4. Account

5. Post a large book

6. Financial statements

\subsection{Bank Financing}

Formal financing is the provision of funds in the form of loans, guarantees, grants, or another financing through banks, cooperatives, and other non-bank financial service institutions (Kemenkop, 2015). According to Law No. 20 of 2008, the efforts of the central and regional governments in improving MSMEs are as follows:

1. Expanding the funding sources and facilitating Micro, Small and Medium Enterprises to be able to bank access credit loans and non-bank financial institution;

2. Increasing funding institutions and expanding its network so that it can be accessed by Micro, Small, and Medium Enterprises;

3. Providing convenience in obtaining funding quickly, accurately, cheaply, and nondiscriminatory in services based on the statutory provisions;

4. Assisting Micro and Small Enterprise actors to obtain financing and other financial services/products provided by banks and non-bank financial institutions, both using conventional and sharia systems with guarantees provided by the Government

Hyz's research (2011) claimed that SME performance in Greece was at a highly unsatisfactory level. There was financing discrimination at MSMEs. Forty-two percent of the surveyed MSMEs felt that the statements from the banks did not meet their needs. In other words, the financing offered by banks was very small. In general, only about $23 \%$ of SMEs turned to banks when they looked for information or advice on financing. According to the company, the next obstacle in accessing banking services was the high interest/bank loan costs, the collateral required by banks, complicated procedures, and the timeconsuming process of obtaining a bank loan. According to a survey, almost $7 \%$ of SME representatives believed that banks asked for information excessively, there are numerous administrative loan application requirements (59\%), lending procedures took long time $(47 \%)$, and around one-third of participants felt that the interest rates were too high $(32 \%)$.

Kurniawati, et al. (2012) examined the accounting reports at MSMEs in Salatiga and stated that the reports included the statement of sales, purchases, inventory of cash flow, costs, and salaries. Accounting reporting was only limited to business management. The obstacles that hamper these MSMEs in the application of accounting are in terms of 
capabilities that included an inadequate educational background and expertise possessed by the owner, resulting in the lack of understanding of the importance of accounting in business management.

Narsa et al. (2012) confirmed that MSMEs with good financial reports had more rapid development compared to other similar age of the MSMEs establishment, or even older. One of the factors that drove the progress of MSMEs was the ability to access credit from banks. Hence, the problem of capital difficulties can be overcome.

Teti and Oktaviani (2017) who conducted MSME research in Kuningan confirmed that $74 \%$ of respondents rated financial reports as being highly crucial in the development process. Based on the data, it indicated that basically, MSME entrepreneurs had assumed that accounting bookkeeping and financial reporting were significant for the growth and development of their businesses, and became an integral part of their business activities. The bookkeeping process and financial reporting had become a concern for MSME entrepreneurs to overcome credit problems and financial management. It might be due to the majority of respondents' educational backgrounds that were not from accounting or economics. Thus, they did not consider bookkeeping to be completed regularly.

\section{Research Methods}

\subsection{Object of research}

The object of research is something that becomes a concern in research. It is the target in research to explore the answers or solutions to problems that occur. Thus, this study researched on the Implementation of Accounting and Financing at Financial Institutions.

\subsection{Population and Research Samples}

The population in this study was the Micro, Small, and Medium Enterprises (MSMEs) in the Provinces of East Java, Central Java, and West Java since those provinces have the most number of MSMEs in Indonesia. The sample in this study was the business with type G (Large and Retail Trade, Repair, and Maintenance of Cars and Motorbikes) since the number of distribution of business types had the highest amount of concentration with retail traders. The determination of samples used in this study was the Probability sampling technique in simple random sampling. Probability sampling is a sampling technique in which the sampling unit is selected based on certain considerations. It aimed at obtaining a sampling unit that met characteristics or criteria in sampling. Simple random sampling is a technique of taking samples from members of the population randomly without considering the strata (levels) in the members of the population. Hence, the sample of the study was seventy-five respondents. It consisted of twenty-five respondents of West Java MSME, twenty-five respondents of Central Java MSME, and twenty-five respondents of East Java MSME.

\subsection{The Operationalization of Variables}

In this study, there were two variables, i.e., the Implementation of Accounting and Financing at Financial Institutions. The implementation of accounting was an independent variable while financing at financial institutions was including as the dependent variable. To provide a clear interpretation, the operational research variables can be observed from the following table: 
Table 1. The operationalization of variables

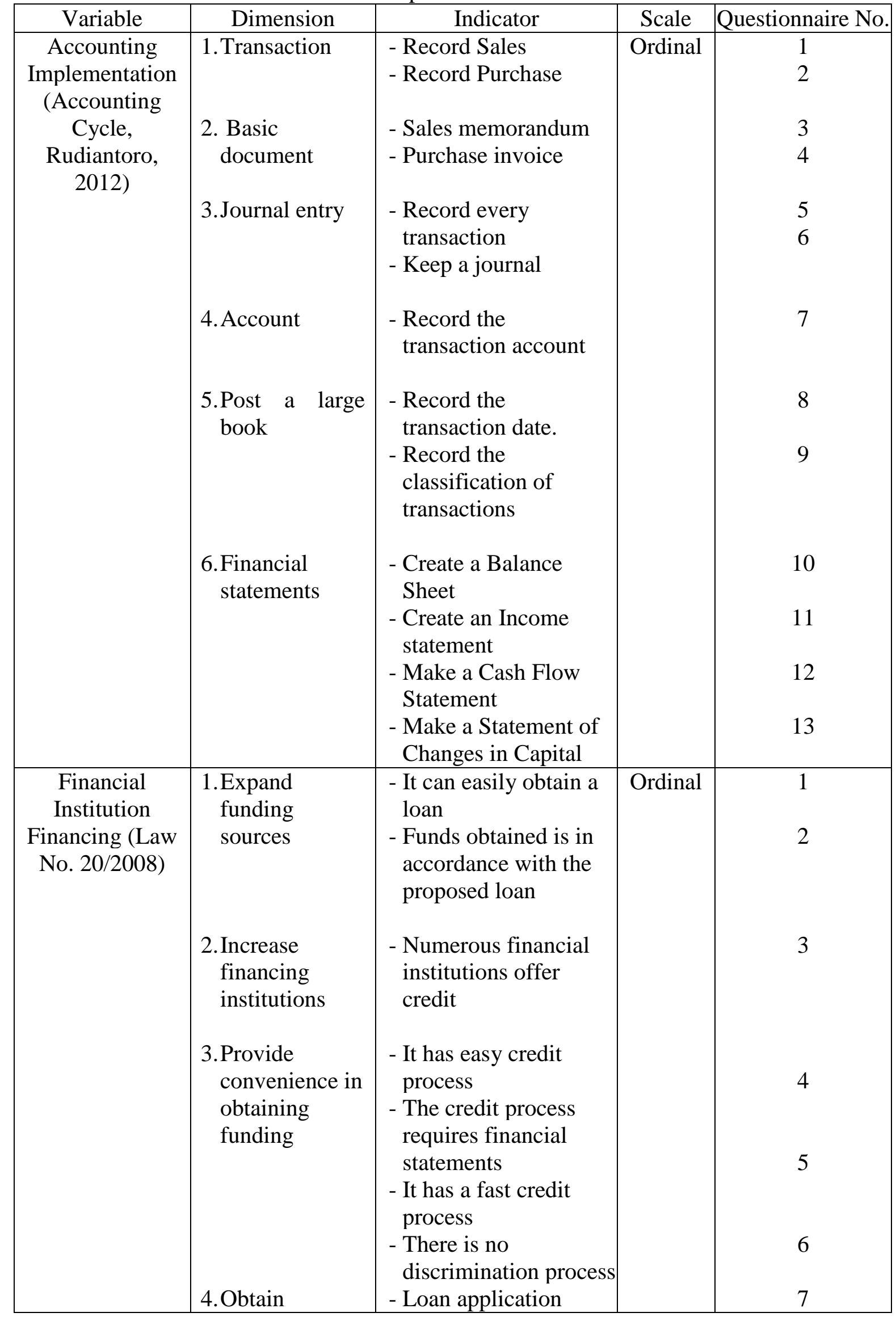




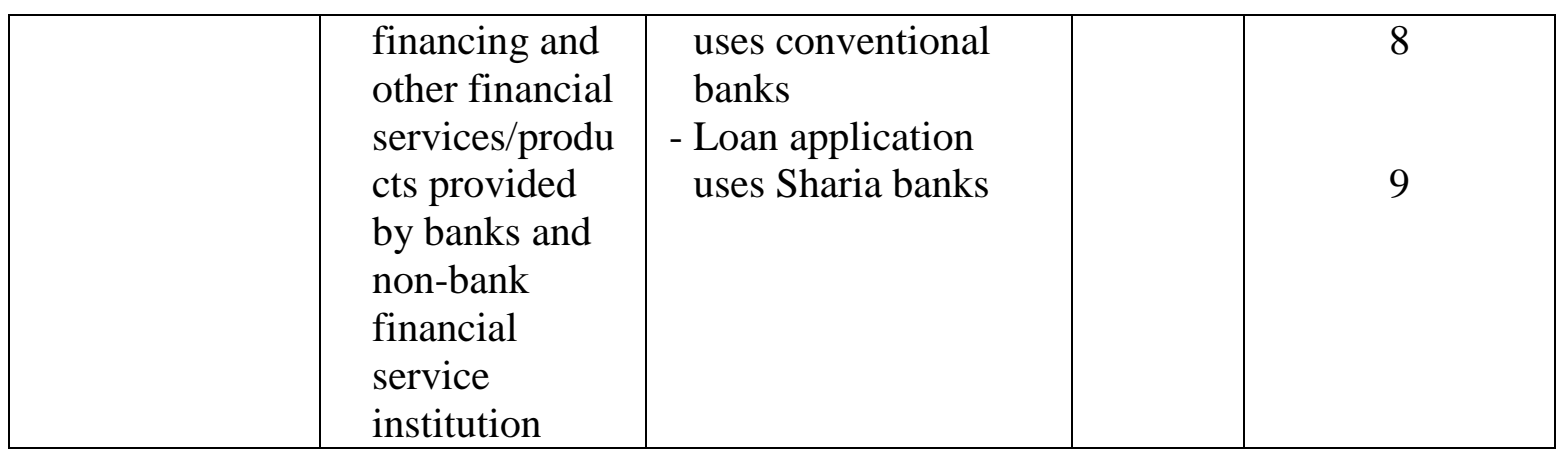

\section{Results and Discussion}

\subsection{West Java}

West Java Province was the second largest province that had MSMEs with 4.5 million number of MSMEs in 2019. The number of government-supported MSMEs was 2500 SMEs (0.0005). Various training was provided to 738 SMEs. MSMEs that applied for credit to financial institutions were 2500 SMEs $(0.0005 \%)$. The number of MSMEs having licenses was 648 SMEs $(0.00014 \%)$. Meanwhile, the number of MSMEs completing financial statements was 738 SMEs (0.000164). The role of the Office of Cooperatives and Small Businesses (KUK) service in promoting SMEs was in the form of training facilities, business meetings, benchmarking, and promotion, both at domestic and abroad, technical guidance on product development, cooperative fair, guidance on access to public finance financing, monitoring and evaluation of banking and non-banking funds, smesco exhibition, digitalization socialization. Meanwhile, MSMEs' contribution to the government was to overcome the problem of poverty and reduce unemployment in West Java. The data was obtained from data and interviews with parties from the West Java Province MSE office.

\subsection{East Java}

East Java Province was the first largest province to have MSMEs in 2019. From the results of data obtained in East Java Province with a total of 38 regencies/cities, East Java had 9.782.262 MSMEs. It consisted of the agricultural MSMEs sectors as the largest number with a total of 5.163.979 MSMEs and from non-agricultural sectors with a total of 4.618,283 MSMEs. Jember Regency had the most MSMEs in agriculture, while Surabaya City was having the most MSMEs in non-agricultural sectors. The number of governmentsupported MSMEs who were provided training in East Java province was 9500 SMEs. MSMEs that applying for credit to financial institutions in 2018 were known to the 337 SMEs but only 227 MSMEs were selected to obtain the credit. MSMEs that had licenses were $21.886(0.002 \%)$ and $9500(0.0009)$ of MSMEs already had financial reports. The role of the Office of Cooperatives and Small Businesses (KUK) service in promoting SMEs was by conducting an IPR Workshop in $27^{\text {th }}-28^{\text {th }}$ of June 2019 , a Small and Medium Enterprises Cooperatives product standardization workshop, IPR consultation guidance and an internal quality Audit Workshop, literacy in Accelerating Access to the Revolving Fund Capital of the East Java Provincial Government to the Women's Cooperatives, SMEs actor and manager of cooperatives, both in the real sector and financial sector, Strengthening of Capital Access for Cooperative and Banking Program Linkage Patterns, and the Technical Guidance for Cooperative Participation Financing Capital Financing. 


\subsection{East Java}

Central Java Province was the third largest province that had 4.131.727 MSMEs in 2019. The role of the government in promoting SMEs was by performing training in marketing development, training for MSME financial management, and product development guidance.

\section{a. Demographics}

From the questionnaire distributed to 75 respondents who participated in the MSMEs, it was revealed that $49 \%$ of them were on the productive age, 31-40 years old. Fifty-three percent of the respondents were women. Thirty-seven percent of the respondents had been in business for 3-6 years. Sixty-seven percent of respondents had sales results of $<\mathrm{Rp}$. 300.000.000, which can be categorized as the micro-enterprise criteria. Forty-six percent of the respondents had a bachelor degree with a net worth of around Rp.50.000.000 - Rp. 500.000.000. The diagram is as follows.

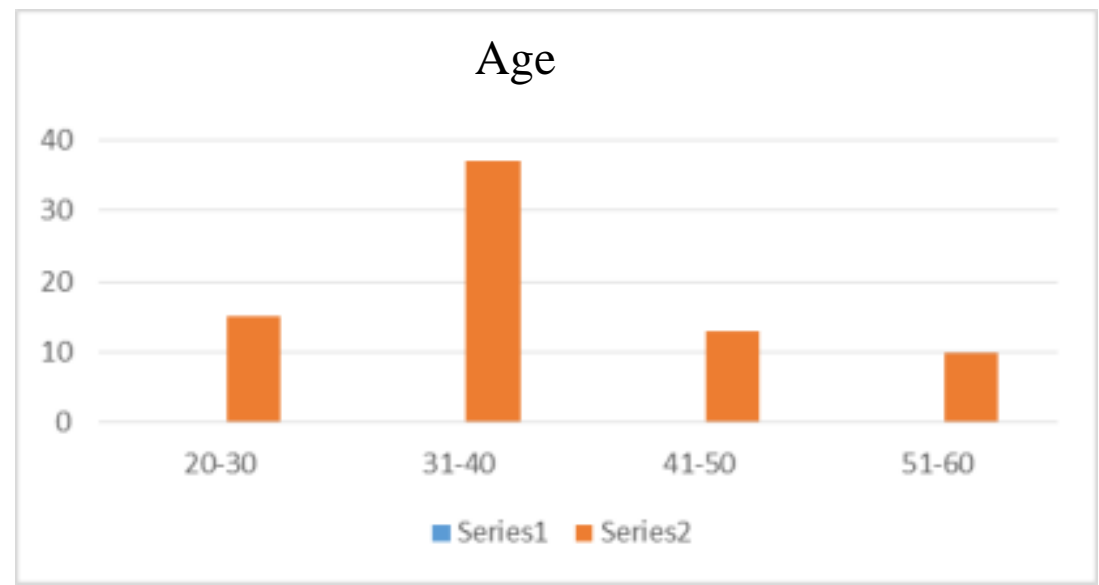

Figure 1. Age Demographics

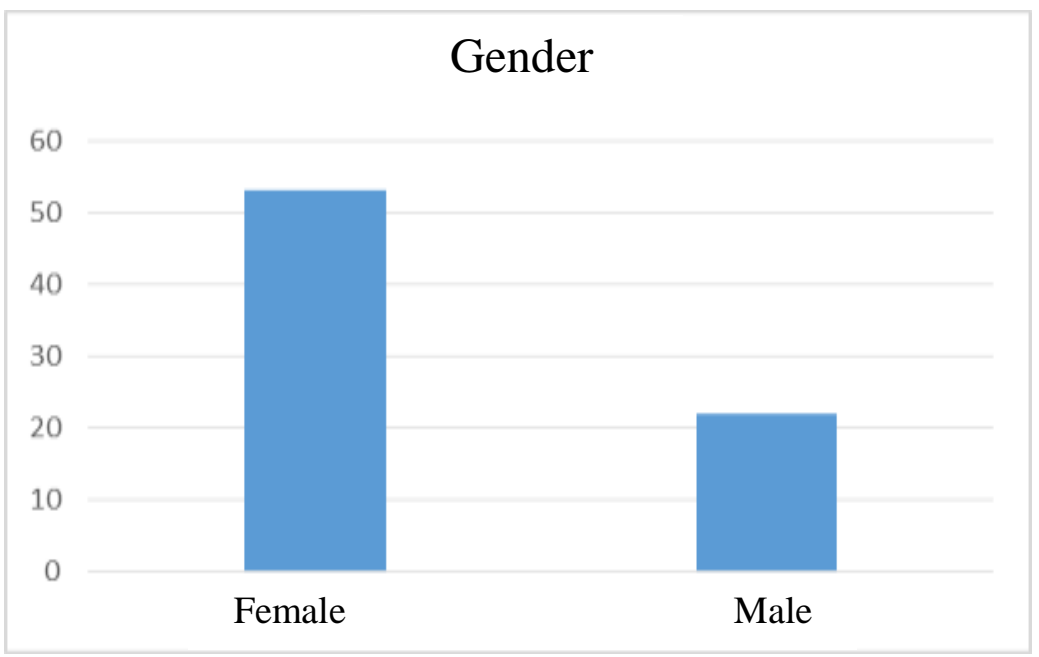

Figure 2. Gender Demographics 


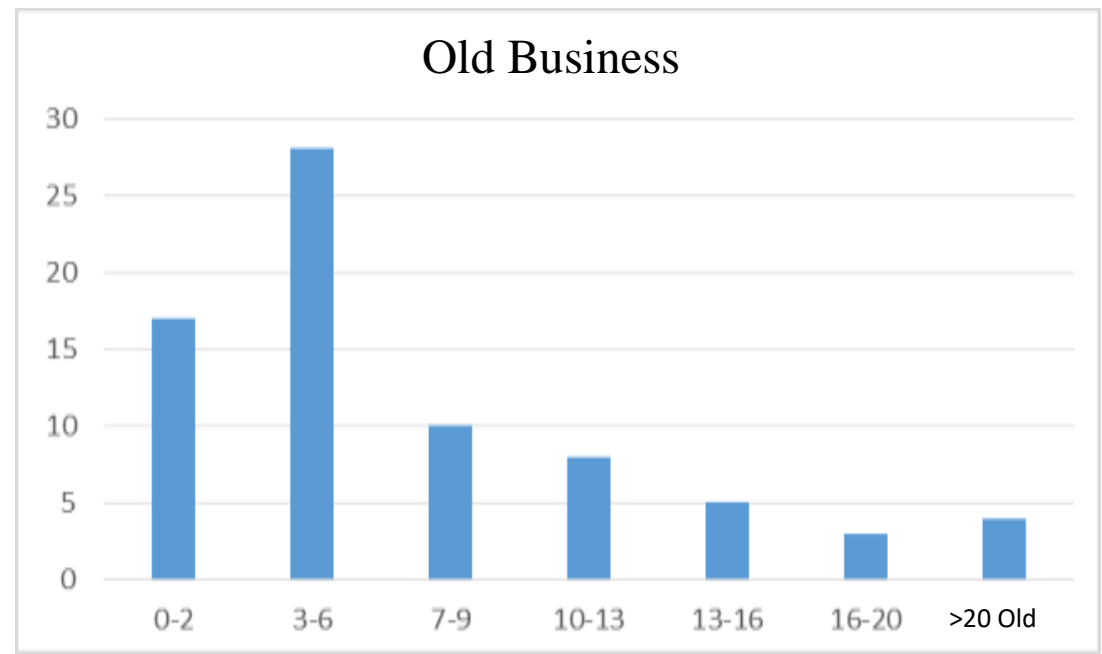

Figure 3. Old Business Demographics

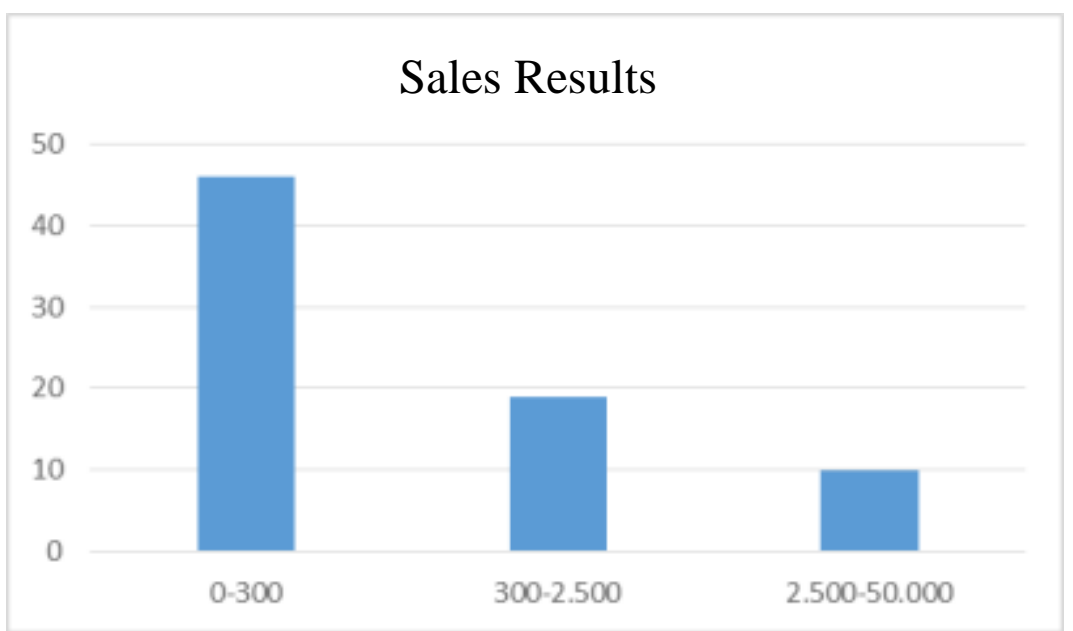

Figure 4. Demographics of Sales Results

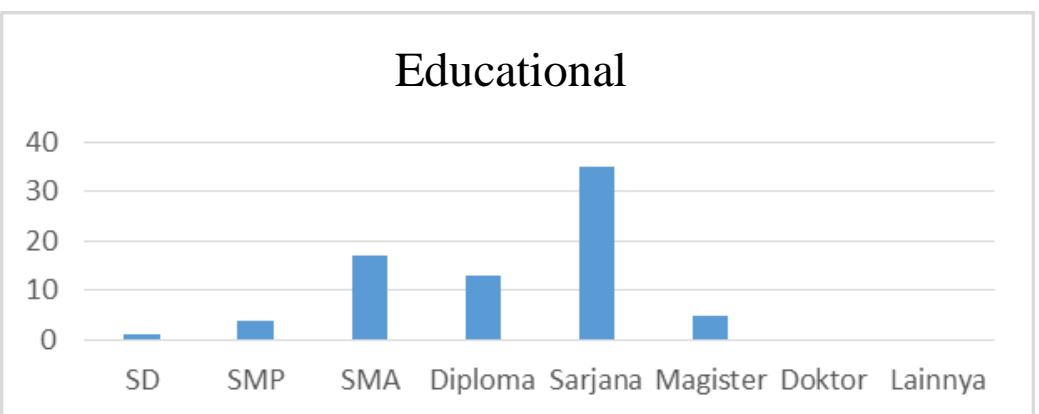

Figure 5. Educational Demographics 


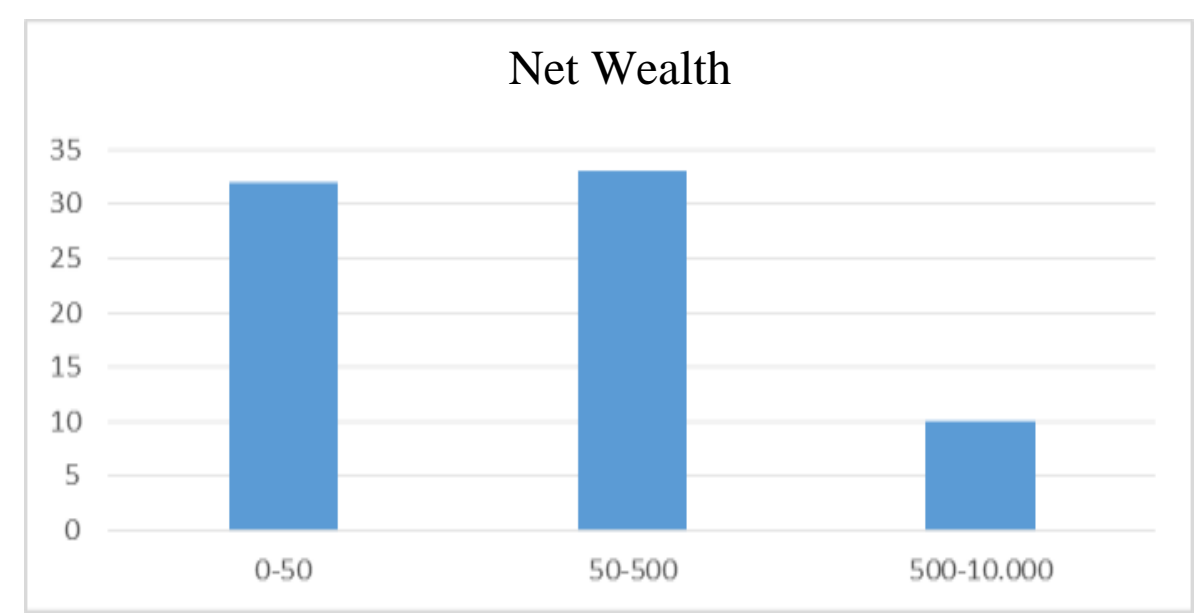

Figure 6. Net Wealth Demographics

\section{b. Validity Test Analysis}

The accounting application is proven to be valid based on the correlation coefficient between item scores and total item scores with a positive and significant result. The higher the value of the correlation coefficient describes the higher degree of validity of the items in measuring the variable. It is observed that the variable items had correlation coefficient

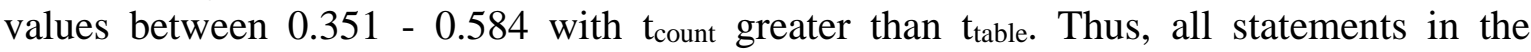
questionnaire for the variable implementation of the budget based on performance were valid. For this reason, the implementation of the performance-based budget variable questionnaire was feasible to be processed as research data.

Analysis of the validity test for the statement of the Financing variable at the Financial Institution (Y) indicated that all Financing items at the Financial Institution were valid. The correlation coefficient between item scores and total item scores was positive and significant. The higher the value of the correlation coefficient describes the higher degree of validity of the items in measuring the variable. It was observable that the variable items had correlation coefficient values between $0.522-0.712$ with $t_{\text {count }}$ bigger than $t_{\text {tabel }}$. Hence, the statements in the questionnaire for the internal audit implementation variable were valid. For this reason, the internal audit implementation variable questionnaire used was feasible to be processed as research data.

\section{c. Analysis of Reliability Tests}

The results of the reliability test of all variables in this study can be viewed in the following table:

Table 2. The reliability test results of the research instrument

\begin{tabular}{|l|c|c|}
\hline \multicolumn{1}{|c|}{ Variable } & Reliability Coefficient & Information \\
\hline Application of Accounting (X) & 0.717 & Reliable \\
\hline Financing at Financial Institutions (Y) & 0.743 & Reliable \\
\hline
\end{tabular}

Source: processed data attachment

The results of the reliability test in the table above illustrated that the variable Application of Accounting (X) obtained a reliability score of 0,717 and the variable Funding in Financial Institutions (Y) obtained a reliability score of 0,743.

It can be viewed that each variable had a reliability coefficient score of $>0,70$. Hence, it can be concluded that all items of each variable and X and Y were reliable and can be further tested. 


\section{d. Descriptive Analysis of the Application of Accounting to MSMEs}

In this section, the survey results were explained along with a qualitative analysis of the accounting Application variable (X). The answers/responses to each statement in the questionnaire are presented in tabular form.

Table 3. Application of Accounting to MSMEs (X)

\begin{tabular}{|c|c|c|c|c|c|c|c|}
\hline \multirow[t]{2}{*}{ NO } & \multirow[t]{2}{*}{ STATEMENT } & \multicolumn{4}{|c|}{ ANSWER } & \multirow[t]{2}{*}{ Total } & \multirow[t]{2}{*}{ Score } \\
\hline & & 1 & 2 & 3 & 4 & & \\
\hline 1 & Conduct sales records in the transaction & & & 14 & 61 & 75 & 286 \\
\hline 2 & Make a purchase record in the transaction & & & 16 & 59 & 75 & 284 \\
\hline 3 & Have a Selling Note & & & 17 & 58 & 75 & 283 \\
\hline 4 & Have a Purchase Orders & & & 15 & 60 & 75 & 285 \\
\hline 5 & Record every transaction in detail & & & 17 & 58 & 75 & 283 \\
\hline 6 & Make journaling of each transaction & 1 & 44 & 23 & 7 & 75 & 186 \\
\hline 7 & Write an account on each transaction & 1 & 24 & 31 & 18 & 75 & 214 \\
\hline 8 & $\begin{array}{l}\text { Record the date of each transaction in the } \\
\text { bookkeeping }\end{array}$ & & & 25 & 50 & 75 & 275 \\
\hline 9 & Classify based on account in bookkeeping & 3 & 33 & 29 & 10 & 75 & 196 \\
\hline 10 & $\begin{array}{l}\text { Make a balance sheet at the end of the } \\
\text { period }\end{array}$ & 8 & 62 & 5 & 0 & 75 & 147 \\
\hline 11 & $\begin{array}{l}\text { Create an income statement at the end of } \\
\text { the period }\end{array}$ & & 10 & 33 & 32 & 75 & 247 \\
\hline 12 & $\begin{array}{l}\text { Create a Cash Flow Statement at the end } \\
\text { of the period }\end{array}$ & 15 & 52 & 6 & 2 & 75 & 145 \\
\hline 13 & $\begin{array}{l}\text { Make a report on changes in the capital at } \\
\text { the end of the period }\end{array}$ & 13 & 45 & 12 & 5 & 75 & 159 \\
\hline & Total & 41 & 270 & 243 & 420 & 975 & 2990 \\
\hline & Percentage & 4.2 & 27.6 & 24.9 & 43.07 & & \\
\hline
\end{tabular}

Source: processed data

The results of the answers given by respondents were then explained by dividing the response scores into classification/grouping range distributions. In this study, the authors divided into four quartile ranges. The application of Accountancy was measured by thirteen statement items. Based on research data obtained from 75 respondents who became the source of research data, for thirteen items as a measure of Accounting Application (X), the Quartile I, Quartile II, and Quartile III, it can be determined through the following calculations:

- Minimum score $=1 \times 13 \times 75=975$

- Maximum score $=4 \times 13 \times 75=3900$

- Quartile II (Median) $=[975+3900]: 2=2437.5$

- Quartile $\mathrm{I}=[975+2437.5]: 2=1706.25$

- Quartile III $=[1706.25+3900]: 2=2803.125$

Furthermore, the assessment scores of variables were classified based on:

- Good : Quartile III $\leq \mathrm{X} \leq$ Maximum Score

- Fair $\quad$ : Median $\leq \mathrm{X} \leq$ Quartile III

- Poor : Quartile $\mathrm{I} \leq \mathrm{X} \leq$ Median

- Bad : Minimum Score $\leq \mathrm{X} \leq$ Quartile I 
From the item score, a total score of 2990 was obtained. Based on the scores of quartile I, quartile II, and quartile III, respondents' responses were classified in the range of scores as follows:

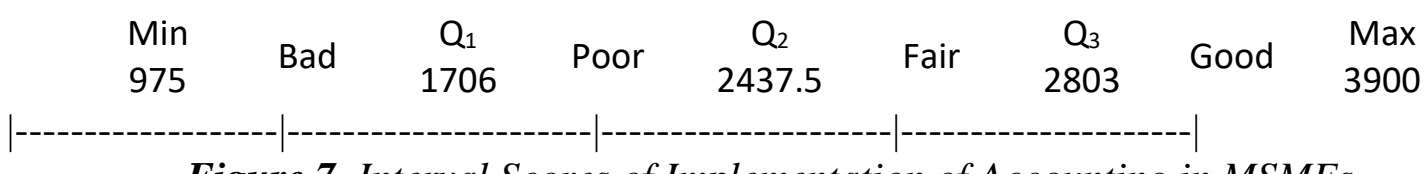

Figure 7. Interval Scores of Implementation of Accounting in MSMEs

It can be observed that the overall Application of Accounting (X) was in a good category. Hence, it can be stated that the implementation of accounting for MSME had been well implemented. Of the thirteen items measuring the level of accounting implementation above, the item "Conduct sales records in the transaction " was part of the implementation of accounting that had the highest value (with a score of 286). Regarding the results of interviews with MSMEs, the thing that is always done in a transaction was a record of sales to buyers as the basis of sales reports each month. As for the item "Create a Cash Flow Statement at the end of the period" had the lowest level of accounting implementation, with a total score of 145 . Based on observations and interviews, reports that were needed only reports of expenses and receipts or income statement only because it is only for personal consumption and submission to the Bank. The other reports according to MSME actors were not too crucial.

\section{e. Descriptive Analysis of Financing at Financial Institutions}

This section explains the survey results accompanied by a qualitative analysis of internal audit implementation variables (X2). The answers/responses to each statement in the questionnaire are presented in tabular form

Table 4. Financial Institution Financing (Y)

\begin{tabular}{|c|l|c|c|c|c|c|c|}
\hline \multirow{2}{*}{ NO } & \multicolumn{1}{|c|}{ STATEMENT } & \multicolumn{3}{|c|}{ ANSWER } & Total & Score \\
\cline { 3 - 6 } & & $\mathbf{1}$ & $\mathbf{2}$ & $\mathbf{3}$ & $\mathbf{4}$ & & \\
\hline 1 & $\begin{array}{l}\text { MSMEs can easily obtain loans from financial } \\
\text { institutions }\end{array}$ & & 30 & 32 & 13 & 75 & 213 \\
\hline 2 & $\begin{array}{l}\text { Funds obtained are in accordance with the } \\
\text { proposed loan }\end{array}$ & 13 & 42 & 12 & 3 & 75 & 155 \\
\hline 3 & Numerous financial institutions offer loans & & & 43 & 32 & 75 & 257 \\
\hline 4 & The loan application process is easy & & 27 & 32 & 16 & 75 & 214 \\
\hline 5 & $\begin{array}{l}\text { Financial reports are required for loan } \\
\text { applications }\end{array}$ & & 20 & 38 & 17 & 75 & 222 \\
\hline 6 & The loan application process is fast & & 53 & 12 & 10 & 75 & 182 \\
\hline 7 & $\begin{array}{l}\text { There is no discrimination in the loan } \\
\text { application process }\end{array}$ & & 11 & 52 & 12 & 75 & 226 \\
\hline 8 & Loan application uses a Conventional Bank & & 12 & 24 & 39 & 75 & 252 \\
\hline 9 & Loan application uses a Sharia Bank & & 43 & 10 & 22 & 75 & 204 \\
\hline \multicolumn{1}{|c|}{ Total } & 13 & 248 & 255 & 164 & 675 & 1930 \\
\hline \multicolumn{2}{|c|}{ Percentage } & & & & & & \\
\hline
\end{tabular}

Source: processed data 
The results of the answers given by respondents were then elucidated by classifying the response scores into range distributions. In this study, the authors classified into four quartile ranges. Funding at a Financial Institution was measured by nine items of the statement. Based on research data obtained from seventy-five respondents who were the source of the research data, nine items as a measure of Financing at Financial Institutions, the Quartile I, Quartile II, and Quartile III, it can be determined through the following calculations:

- Minimum Score $=1 \times 9 \times 75=675$

- Maximum Score $=4 \times 9 \times 75=2700$

- Quartile II $($ Median $)=[675+2700]: 2=1687.5$

- Quartile $\mathrm{I}=[675+1687.5]: 2=1181.25$

- Quartile III $=[1687.5+2700]: 2=2193.75$

Furthermore, the assessment scores of the internal audit implementation variables were classified based on:

- Good : Quartile III $\leq \mathrm{X} \leq$ Maximum Score

- Fair $\quad$ : Median $\leq X \leq$ Quartile III

- Poor : Quartile $\mathrm{I} \leq \mathrm{X} \leq$ Median

- Bad : Minimum Score $\leq \mathrm{X} \leq$ Quartile I

From the item scores, the total Financial Institution Financing score was 1930. Based on the scores of Quartile I, Quartile II, and Quartile III, respondents' responses were classified in the following range of scores.

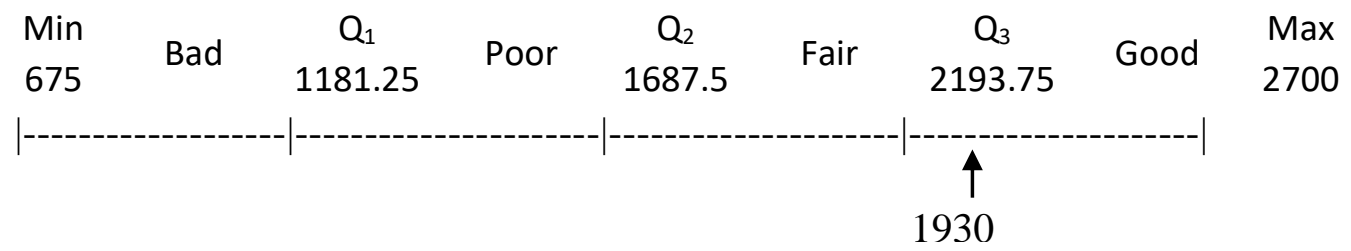

Figure 8. Financial Institution Financing Total Score Interval

It can be viewed that the overall financing at Financial Institutions (Y) was in a sufficient category. From the nine items measuring the level of Financing in Financial Institutions, the item "There are numerous financial institutions that offer loans" statement at the item number three obtained the highest score with a total of 257 compared to other items. Thus, it can be concluded that numerous financial institutions offer loans to MSMEs. The item "Funds obtained is in accordance with the proposed loan", in statement number two, had the lowest score among other items with 155 of the total score. Based on the results of the interview, it occurred due to consideration of the size of the business, place of business, duration of business, and business license. Banks disbursed funds by evaluating these aspects.

\subsection{The Relationship of Accounting Application to Financing by Financial Institutions}

The results of hypothesis testing conducted in this study depicted that the application of accounting has a positive and significant effect on financing by financial institutions. It is based on statistical test results obtained by the path coefficient $=0.455$ with a significance value of $0.022<0.05$. Therefore, that $\mathrm{H}_{0}$ was rejected and $\mathrm{H}_{1}$ was accepted. It can be concluded that the better the application of accounting (X), the more optimal is financing by financial institutions (Y). 
The coefficient of accounting and financing application by financial institutions was 0.455 , and the direct effect was $20.7 \%$. It means that according to the Guiford category, the influence was moderate. There were $76.2 \%$ of the other variables effect (epsilon) outside the effect of $\mathrm{X}$ that was not examined. The following is a table that shows the results of statistical calculations using SPSS.

Table 5. Correlation Coefficient and Hypothesis determination

Model Summary

\begin{tabular}{|l|r|r|r|r|}
\hline Model & \multicolumn{1}{|c|}{ R } & R Square & Adjusted R Square & Std. Error of the Estimate \\
\hline 1 & $.455^{\mathrm{a}}$ & .207 & .215 & 2.93570 \\
\hline
\end{tabular}

a. Predictors: (Constant), $\mathrm{X}$

From the results of statistical analysis, it can be found that the effect of accounting response on financing by financial institutions was $20.7 \%$ and the remaining $76.2 \%$ or the influence of other variables (epsilon) outside the influence of $\mathrm{X}$ that is not examined. Based on the results of interviews with MSMEs for financing by financial institutions, the main aspects were permit and ownership of the place of business

\section{Conclusion}

In general, the application of accounting had been done by numerous MSME actors, especially in the aspect of recording sales. However, there were only a few aspects that had not been maximized, i.e., making cash flow and balance sheet reports for MSME actors. Providing credit to financial institutions for MSMEs was considered sufficient by MSMEs. It means that it had not been maximized in giving loans that have the highest value, in which there were many institutions offering loans. Meanwhile, the funds obtained are in accordance with the proposed loan to the lowest value in the variable credit to financial institutions.

\section{References}

Angelia, N. et al. (2020). Analysis of Community Institution Empowerment as a Village Government Partner in the Participative Development Process. Budapest International Research and Critics Institute-Journal (BIRCI-Journal). P. 1352-1359.

Blueprint Pembiayaan Koperasi, Usaha Mikro, Kecil dan Menengah Tahun 2015-2019

Kieso, D. E., Weygandt, J. J., \& Warfield, T. D (2011). Intermediate Accounting Volume 1 IFRS Edition. United States of America : Wiley

Kurniawati P.E, Paskah I N \& Chandra A (2012). JMK, Vol 10 No. 2, September 2012. Informatics and Business Institute Darmajaya

Maseko, N. and O. Manyani. 2011. AccountingPractices of SMEs in Zimbabwe: An Investigative Study of Record Keeping forPerformance Measurement (A Case Study of Bindura). Journal of Accounting andTaxation, 3 (8), 171-181

Narsa, et al (2012). Mengungkap kesiapan UMKM dalam Implementasi Standar Akuntansi KEuangan Tanpa Akuntabilitas Publik (SAK ETAP) untuk meningkatkan Akses Modal Perbankan. Majalah Ekonomi. Vol XXII No.3

Presiden Republik Indonesia. 2008. Undang- Undang Republik Indonesia Nomor 20 Tahun 2008 Tentang Usaha Mikro, Kecil Dan Menengah 
Rahmawati Teti dan Oktaviani R Puspasari (2017). Implementasi SAK ETAP Dan Kualitas Laporan Keuangan UMKM Terkait Akses Modal Perbankan”. Jurnal Kajian Akuntansi, Vol 1, (1), 2017, 49-62

Rudiantoro Rizki dan Sylvia V Siregar (2012). "Kualitas Laporan Keuangan UMKM Serta Prospek Implementasi SAK ETAP" Jurnal Akuntansi dan Keuangan Indonesia Volume 9 - No. 1, Juni 2012

Sekaran, uma dan Roger Bougie. (2010). Edisi 5, Research Method For Business: A Skill Building Approach. John Wiley @ Sons, New York

Sugiarto (2012). Pengantar Akuntansi Edisi 2. Universitas Terbuka 